\title{
Diamond-Based Nanostructured Materials for Detection of Water Contaminants
}

\author{
A. V. Girão $1 \square$ \\ Email avgirao@ua.pt \\ M. A. Neto 1 \\ F. J. Oliveira 1 \\ R. F. Silva \\ 1 CICECO - Department of Materials and Ceramic Engineering, Universidade de Aveiro, Campus de Santiago, 3810-193, Aveiro, Portugal
}

\section{Abstract}

Sustainability is presently one of the most heard watchwords. Water environment is of great importance to all living beings and climate changes, with cleaning and preservation of our largest natural resource as the number one priority. It can only be attained if environmental conscience is put into practice and, involuntarily or not, the scientific community inherited the additional responsibility to cope with the urgency of this matter. This chapter offers a closer look at diamond-based nanostructured materials for detection of water contaminants. This group of synthetic materials has remarkable electrochemical properties towards sensing and analysis of water pollutants such as heavy metals, pesticides or pharmaceutical compounds. Moreover, doped-diamond thin films provide endless applications as electrodes in environmental monitoring but also as strong tools already being applied in environmental remediation. Diamond-based nanostructured electrodes are suitable for the wide range of electrochemical techniques providing fast, straightforward, sensitive, reproducible and robust means of electroanalysis. The versatility of these electrodes also enables in situ and real time application as sensitive and stable sensors also if being tested for determination of contaminants in complex water matrices.

\section{Keywords}

Diamond

Thin films

Electrochemical sensors

Environmental monitoring

Electroxidation

Water treatment 


\section{Environmental Monitoring}

Sustainability is probably the most noticeable up-to-date word. Its concept is quite complex, particularly if we are no longer able to maintain a good quality level of ecological balance. The human and biosphere relationship has been severely compromised, we are now starting to pay for the constant human abuse of the ecosystem and global warming is here to stay with unknown endurance. Thus, it is now imperative that the economic, environmental and social aspects of sustainability are encouraged in the right direction enabling the future generations the capacity to meet their needs and retain that behaviour repeatedly.

Environmental sustainability consists in the rates of renewable resource return, pollution creation and non-renewable resources exhaustion that can be continued indefinitely, as defined by Daly in the 1990s [1]. Nevertheless, one of the three pillars of sustainability has always been the overlooked one. Economic wellbeing and social fulfilment grew at the cost of environment degradation. The latter is mainly due to human pollution of the environment, with the lack of vision and/or concern for the short, medium and long-term implications.

Pollution can be defined as the direct (or indirect) contamination of the environment in such matter that it causes potential or real harm or damage to all living beings on Earth. Either in the form of streams, lakes, rivers or oceans, water covers around $70 \%$ of our planet, becoming the main resource affected by pollution. Moreover, the hydrological cycle is the perpetual circulation of pollutants between atmosphere, soil water, surface water and ground water. Currently, aquatic pollution has become such a multifaceted problem that it needs to be tackled in its different fronts via diverse tactics. Most of the occurring, or emerging, water pollutants have been acknowledged but it still is necessary to identify, quantify and, if possible, accurately eliminate their presence.

The first approach can be carried out by monitoring our aquatic environment quality in order to control it. The process of studying and data collection result in valuable information on the environment state which, in its turn, provides better understanding of the pollution problem. Monitoring can only be carried out using new and better technology, keeping up with the fast advances in microminiaturization of the analytical instrumentation. Sensors, as any other type of analytical equipment, needs to fulfil several requisites in order to be feasible aiming at its recognition and consequent commercialization. Thus, obtaining realtime and in situ information leads to early warning and precise risk assessment with consequences in environment policies, enabling the making of wellinformed political, economic and social decisions. Hence, the previously disregarded pillar becomes the starting point to a balanced sustainability.

The main objective of this chapter is to provide insight on the effective application of diamond-based micro/nanostructures used as sensors for aquatic pollutants. This group of materials used as sensors has already proven to be a valuable alternative to the more elaborated and expensive sensors for pollutants detection. The chapter begins to explore the nanoscience opportunities in environmental monitoring, followed by a brief inspection at diamond electrochemistry, in the nanoscale range. The application of diamond-based sensors is also presented according to the nature of the environmental pollutants. The reader will also be provided with general application of such materials onto technology for environmental remediation. Ultimately, the concluding remarks include the challenges and future perspectives for diamond-based micro/nanostructured materials in aquatic pollution.

\subsection{Nanoscience and Sensors}

Nanotechnology unlocked a wide range of opportunities for environmental purposes. Nanomaterials typically present size and shape dependent physicochemical properties, high reactivity level and large specific surface area [2]. Thus, chemists and engineers have long exploited and tailored the properties of nanomaterials accordingly to their application, including environmental remediation and monitoring. Nanostructures were primarily used in separation processes as sorbents or membranes for removal of sulphur compounds from fuels or heavy metals from wastewater. Heavy metals nanoadsorbents included clays, metal oxides, carbonaceous or metal-based nanomaterials [3]. New trends in analytical analysis were rapidly developed and the sensors area of application broadened 
|environmental monitoring from gas sensors (metal oxides or graphene) to biosensors (enzymes, aptamers or antibodies) [4-8]. Consequently, new and more effective environmental remediation processes have been applied. Therefore, nanotechnology implementation brought numerous advantages in terms of sensors with higher sensitivity and selectivity and enabling measurements at the nanoscale range as well as reducing sampling needed for analysis.

Sensors are tools or devices that are sensitive and responsive to a certain external interaction that takes place via heat, pressure, strain, magnetic or electric field, radiation or chemical reaction. The response and information are then sent to electronics which processes and converts them to a well-known signal for interpretation. Depending on their application, there are several types of nanomaterials-based sensors for environmental monitoring. The existent groups of sensors can be divided according to the type of physicochemical interaction between the sensor and the analyte besides the different signal transduction mechanisms. There are optical sensors based in the phenomena of fluorescence, colorimetry, plasmonics or surface/enhanced Raman scattering. In addition, there are also optofluidic or microfluidic sensors or electrochemical sensors [4-9]. Sensors performance is assessed according to several requirements such as sensitivity, selectivity or detection limit, fast response, stability and robustness. Thus, reliable sensing technology is highly needed including the design and fabrication of platforms for the sensors, real time and in situ monitoring, multitarget detection, portability and possible remote control of such devices. In a sensor quality assessment, production and maintenance costs are also accountable [4-11].

This chapter focuses on the use of diamond-based micro/nanostructured materials as aquatic environmental monitoring electrochemical-sensors. As in any other environmental monitoring media, sensing in aquatic environments must be followed by reliable quantification measurements of the pollutants in order to suitably control water pollution. The next section introduces general concepts regarding diamond-based micro/nanomaterials and their effective application as electrochemical sensors in environmental monitoring of water media. These sensors offer several advantages over many other sensing techniques and nearly fulfilling most of the requirements for a suitable sensor performance.

\section{Diamond Electrochemistry}

Diamond has always attracted the attention of scientists besides the public one. It is an extremely hard carbon crystalline form with application in many research areas. Its interest has been further extended by the production of polycrystalline diamond ( $\mathrm{sp}^{3}$ carbon) films presenting mechanical and electronic properties like those of naturally occurring diamond. Currently, synthesis of diamond thin films uses the chemical vapor deposition (CVD) technique in which gaseous mixtures of hydrocarbons and hydrogen are thermally, radiofrequency or electrically activated, resulting in diamond growth onto the surface of a nondiamond substrate, at sub-atmospheric pressure. Thus, depending on the gas activation process the CVD technique for diamond growth is better known by direct current (DC)-plasma [12], radiofrequency (RF)-plasma [13], microwave plasma enhanced (MPE)-CVD [14], electron cyclotron resonance (ECR)-plasma [15] and hotfilament (HFCVD) [16]. Other non-CVD methods for diamond thin film deposition have also been employed such as low- and high-energy carbon ion beams, low pressure or low temperature diamond growth or electron bombardment of the substrate [17-19], as illustrated in Fig. 1.

\section{Fig. 1}

Diagram illustrating different diamond thin film deposition techniques 


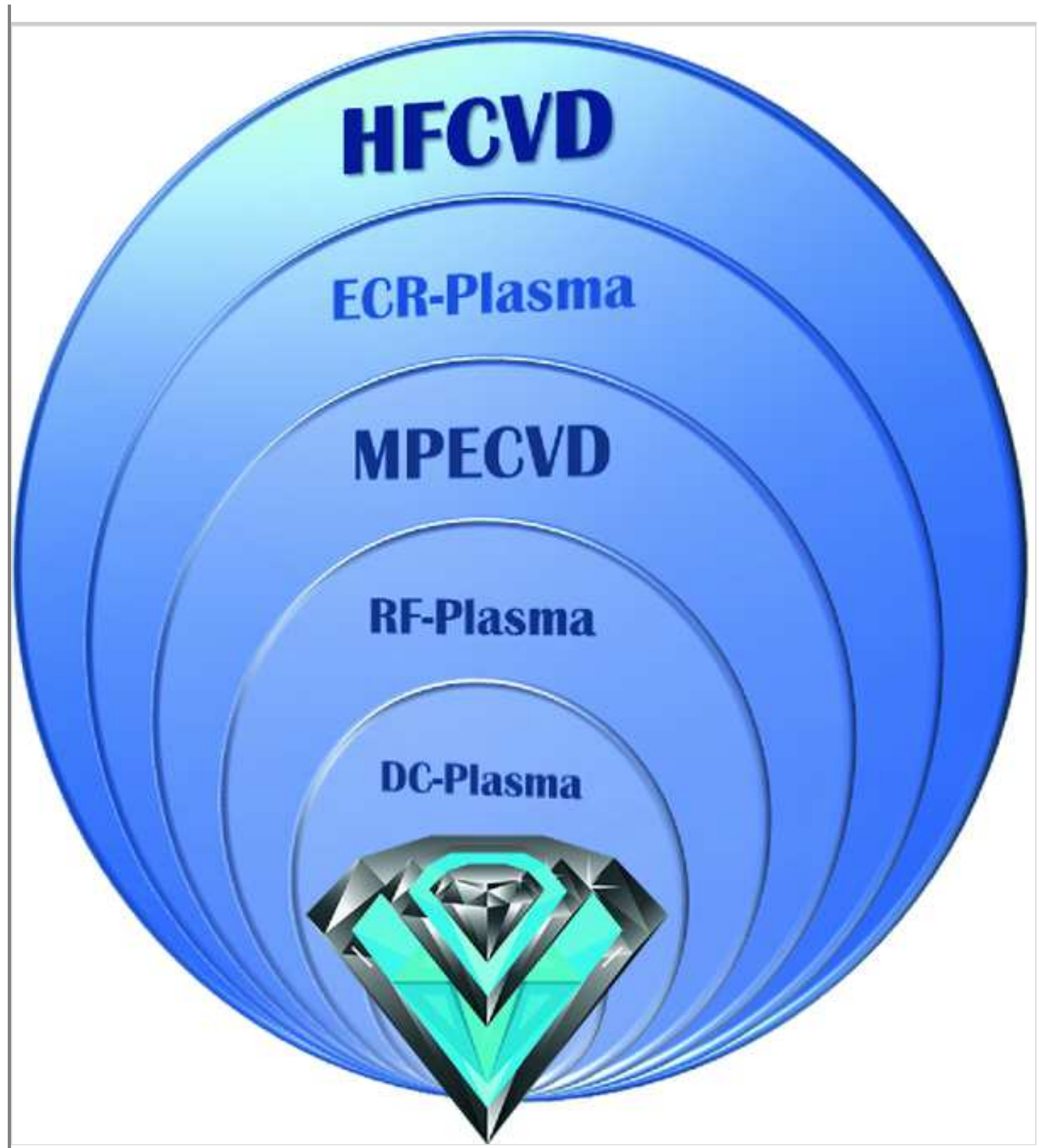


Synthetic strategies have also been reported for distinct diamond micro and nanostructures such as nanoneedles, rods or forests, nanotextures like nanograss, winkles or cones, and networks (Fig. 2), typically tailored recurring to masks or bottom-up approaches, with effective advanced electrochemistry applications [17-19].

\section{Fig. 2}

Scanning electron microscopy images illustrating different diamond micro and nanostructures: a-d microcrystalline diamond thin film; microcrystalline diamond thin film; f nanocrystalline diamond thin film; $\mathbf{g}$ nanorod forest.

Reproduced with permission from reference [20], Published by Hindawi Publishing Corporation 
(a)
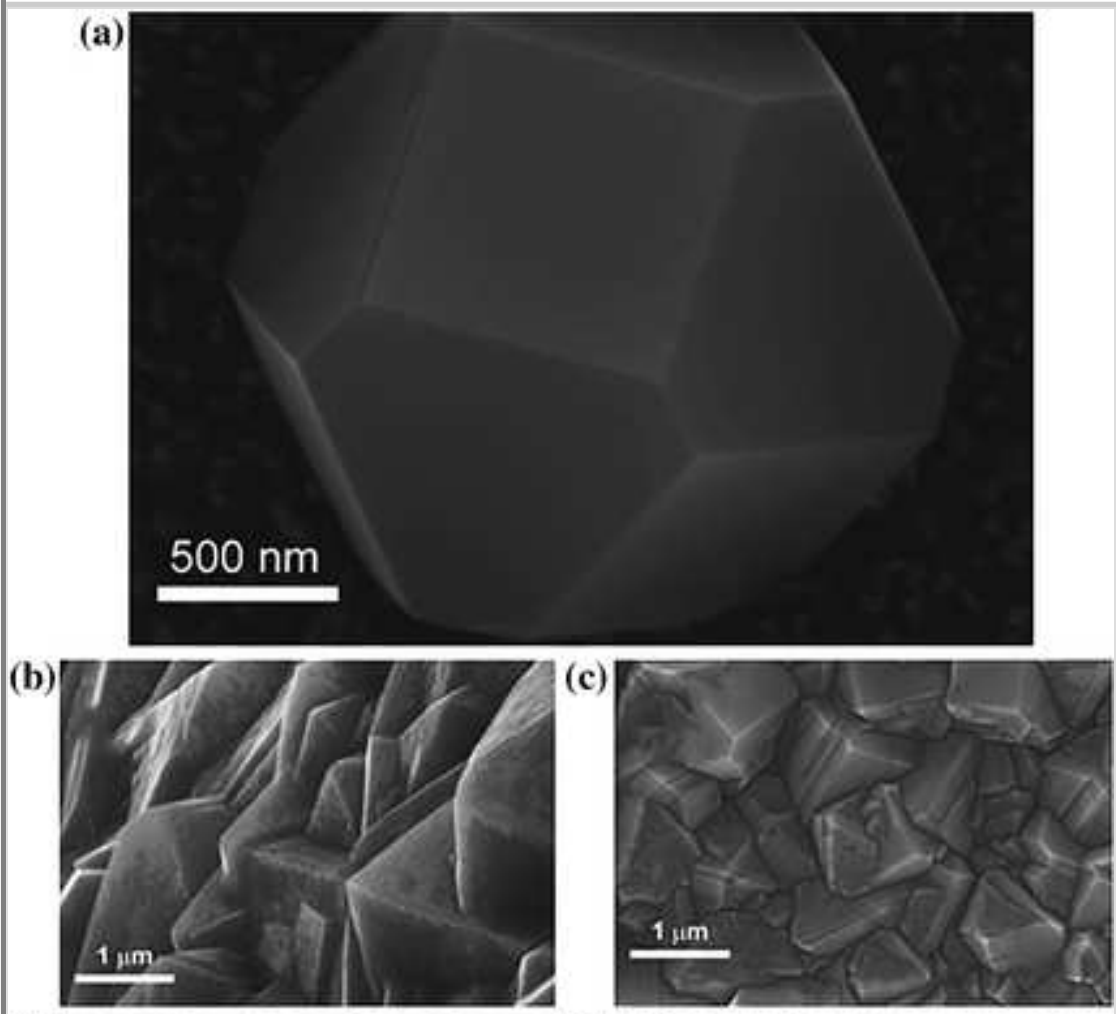

(d)

(e)
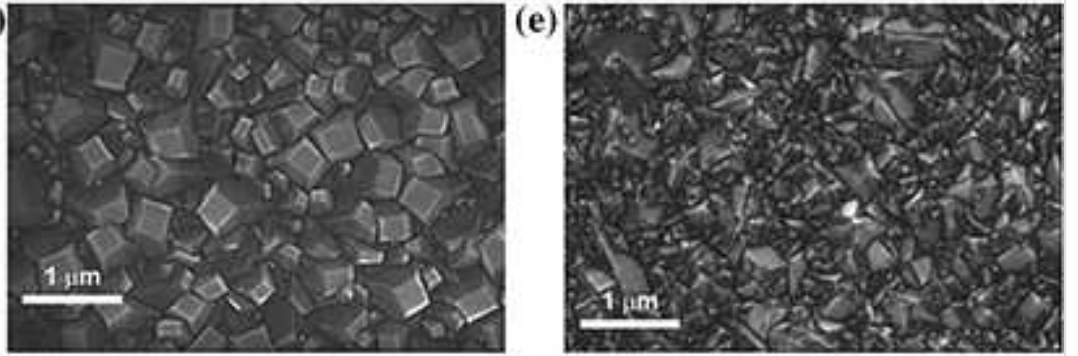

(f)

(g)
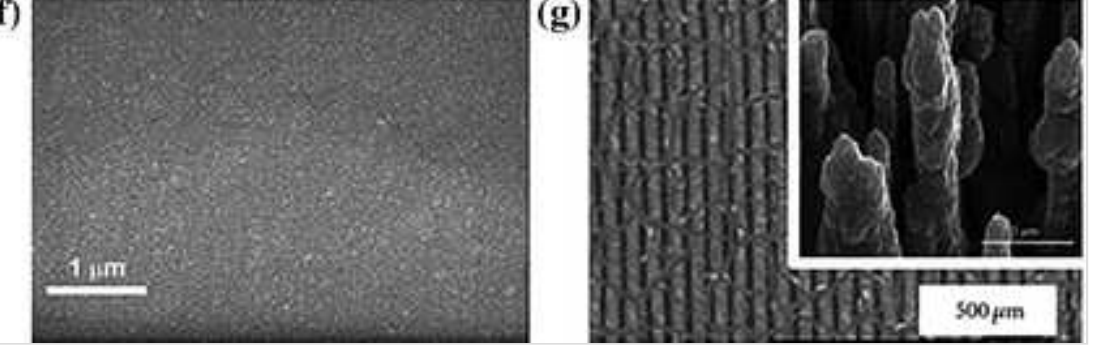
Electroanalytical methods use low cost instrumentation, are highly sensitive and present outstanding low detection limits for the multidetermination of trace amounts of many compounds. Therefore, electrochemical and bioelectrochemical methods have become excellent techniques to make use of diamond-based electrodes. Traditional carbon electrodes like glassy carbon, graphite, or carbon fibers, cloths and nanotubes, are low cost and of simple preparation, presenting large surface area and wide potential window of water stability. Although with application in batteries and double-layer capacitors or sensors, these materials still have downsides such as long-term stability or limited detection of compounds oxidizing at relatively high anodic potentials in water. Thus, interest in testing and using diamond thin films as electrodes naturally came into sight bearing in mind the extraordinary properties that nanomaterials have to offer. Moreover, smaller dimension within the micro/nano range benefits the electrodes performance since, theoretically, the measurement rates and mass transport are enhanced and Ohmic resistance is reduced as well as charging currents and the poisonous effects of electrolyte resistance. The interfacial properties and electrochemical behavior of diamond nanostructures have been characterized by different electrochemical techniques and it is generally accepted that the dimensions, morphology and surface termination of the nanostructures play a significant role on diamond electrochemical performance [17-19]. Diamond-based nanostructured electrodes have been explored to some extent as electrochemical and bioelectrochemical sensors for analytes such as nitrite or hydrogen peroxide, and glucose or dopamine [17, 19,21]. In addition, diamond is chemically and biochemically inert, with little or no cytotoxic response, which has widely opened its use in biomedical instrumentation and devices [22, 23]. Finally, diamond-based nanostructures have also found use in electrochemical energy storage as capacitors/supercapacitors, in electrocatalysis, filtration systems, corrosion inhibition or surface-sensitive adsorption phenomena [19].

\subsection{Doped Diamond}

In the 1980s, Iwaki et al. [24] was the first one reporting on the use of ion implanted diamond as an electrochemical electrode, and Pleskov et al. [25] studied the photoelectrochemical behavior of an electrode made of semiconducting diamond, followed in 1992 by Fujishima and coworkers [26]. Diamond is a semiconductor with a very wide bandgap $(5.47 \mathrm{eV}$, at $300 \mathrm{~K})$ but like many "insulators", its bandgap can be significantly narrowed down by appropriate doping. The latter is usually carried out using either nitrogen ( $n$-type dopant, activation energy of $1.7 \mathrm{eV}$ ) or boron ( $p$-type dopant, activation energy of $0.37 \mathrm{eV}$ ), amongst others. Boron is the most used dopant due to its lower activation energy and efficient replacing of carbon within the diamond crystalline structure. Heavy boron doping is then possible, imprinting a metallic character to the diamond and resulting in a diamond thin film with high electric conductivity. Consequently, much of electrochemical research also turned its purposes at exploring boron doped diamond (BDD) electrodes [17, 18, 21, 27]. CVD is the most used synthetic route to prepare BDD thin films since it enables effective control of the doping process and follows the same principle as previously described. Basically, the use of a hot filament (or microwaves) creates a plasma whose resulting high temperature generates carbon radicals and relatively high concentrations of disassociated hydrogen; the carbon/hydrogen gas phase source is fed to the chamber then a boron gas phase is simultaneously fed into the CVD chamber; and, under suitable surface kinetics conditions, BDD growth takes place. Equally important in diamond thin film CVD processes, the deposition conditions (gas composition, temperature, time, pressure, etc.) are vital since they will dictate the final properties of the films such as the surface morphology, growth rate, diamond quality ( $\mathrm{a} \mathrm{sp}^{2}$ to $\mathrm{sp}^{3}$ ratio) $[28,29]$, grain size and, consequently, orientation of the polycrystalline BDD thin film. A noble gas such as argon can also be added to the gas phase mixture enabling the control of the grain size range of the BDD crystallites. Thus, it is possible to obtain ultrananocrystalline (UNC) BDD with grain size $<10 \mathrm{~nm}$, nanocrystalline (NC) BDD with grain size $10 \mathrm{~nm}-1 \mu \mathrm{m}$ and microcrystalline (MC) BDD with grain size $>1 \mu \mathrm{m}$. Additionally, one can only assume that the boron content is also affected by the crystallites orientation and that polycrystalline BDD thin films are heterogeneously doped. Ultimately, boron doping plays an important role on the final electrochemical properties and consequent applications [17, 18, 21, 27, $30]$.

Surface termination ( $\mathrm{H}-$ or $\mathrm{O}-$ ) is an important aspect in BDD thin films [31]. It affects the electron transfer kinetics of inner sphere redox processes (surface sensitive), wetting properties and polarity of the electrode surface. In H-terminated surfaces (grown samples in most CVD techniques), both valence and 
conduction band energy levels are increased, but the conduction band is still above the vacuum level revealing a negative electron affinity at the surface which, in its turn, once the electrode contacts an aqueous solution, a positively charged layer is formed at the surface resulting in a measurable surface conductivity. Hydrogenated surfaces are hydrophobic to a certain extent, though they are quite stable in air for a considerable amount of time, slow oxidation always takes place and with time they start showing a less hydrophobic character [32]. Surface hydrogenation can also be achieved by hydrogen plasma treatment or cathodic polarization. In contrast, O-termination of the surfaces are typically hydrophilic (opposite effects of those of H-termination) and is easily accomplished through oxygen plasma treatment, anodic polarization, acid attack at boiling point or alumina polishing [21, 27, 30]. Figure 3 schematically shows the contact angle in hydrogenated and O-terminated BDD surfaces.

\section{Fig. 3}

Scheme illustrating the different contact angles observed in hydrogenated (left) and O-terminated (right) BDD surfaces

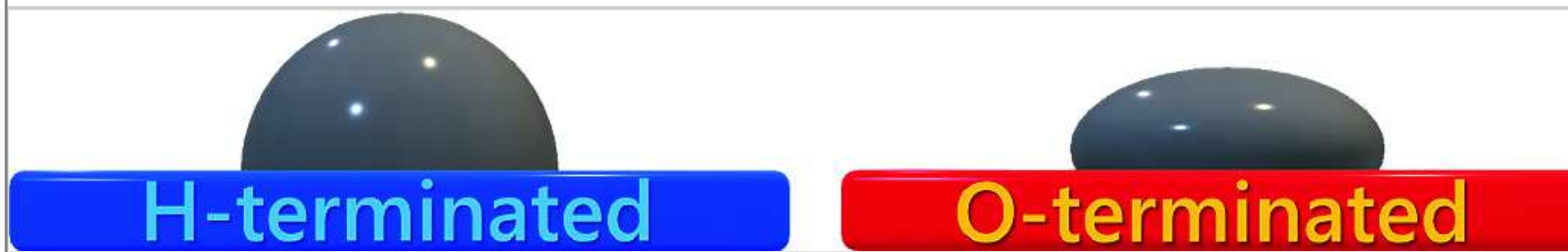

Surface assessment and accurate chemical information can be given by X-ray photoelectron spectroscopy (XPS). Another important aspect that should also be considered is surface reactivity attained by chemical, photochemical, thermal or electrochemical functionalization methods, depending on the desired application $[18,21,27]$.

BDD thin films offer exceptional electrochemical properties with many advantages over the classic and expensive metal or other sp ${ }^{2}$ electrodes. They have a very wide potential window, corrosion stability in aggressive media, and low background currents in aqueous and non-aqueous electrolyte media. Therefore, BDD thin films are subject of considerable interest for the last few decades as an electrode material with effective application in electrochemical and bioelectrochemical techniques. Different morphologies or synergistic effects with other materials to improve the BDD thin films performance have also been explored [33-35]. Other applications such as microelectrodes arrays tested as new amperometric sensors for high-performance liquid chromatography detectors $[36,37]$, neuroengineering of neural interfaces and networks [38], in vivo nerve electrical recordings [39], or detection of dissolved oxygen and pH [40], or microfluidics [41] were also reported.

\section{Doped Diamond Sensors}


The identification and/or determination of certain adverse effects on human health is far from straightforward. Frequently, the effect is identified but its risk factor(s) existing in the environment are not always notorious. Therefore, risk factor assessment is essential and completed in four steps: the " $b a d$ " substance with adverse health effects (hazard) is identified; the circumstances for exposure to the substance are documented; the health effects are categorized; and the probability of occurrence (or risk) of such health effects is estimated. Then, based on that risk assessment, the limit of acceptable concentration of a certain hazard is decided [42]. Many variables are involved, it may take years or decades to accurately assess a risk factor and every so often such concentration can only be determined, in retrospective, like it happened with the Chernobyl nuclear reactor accident.

Water pollutants may be categorized as point source corresponding to pollutants generated in industrial facilities and municipal wastewater treatment plants enters watercourses, and nonpoint source like storm drainage or farm overflow, construction locations or other land disturbances [43]. The extensive list of aquatic pollutants includes heavy metals such as lead, cadmium, copper or zinc; pesticides like ziram, picloram or propoxur; phenol and its derivatives;

pharmaceutical compounds such as neurotransmitters or antibiotics; pathogens like Escherichia coli; and potentially hazardous biomolecules such as harmaline or caffeine.

This section is fully dedicated to the application of doped diamond sensors for the detection and/or quantification of specific aquatic pollutants. So far, BDD thin films have been extensively explored and the nanostructured material presenting the most effective application in environmental monitoring. Figure 4 illustrates the different environmental monitoring application of doped-diamond thin films.

\section{Fig. 4}

Diagram illustrating the different environmental monitoring applications of doped-diamond thin films 


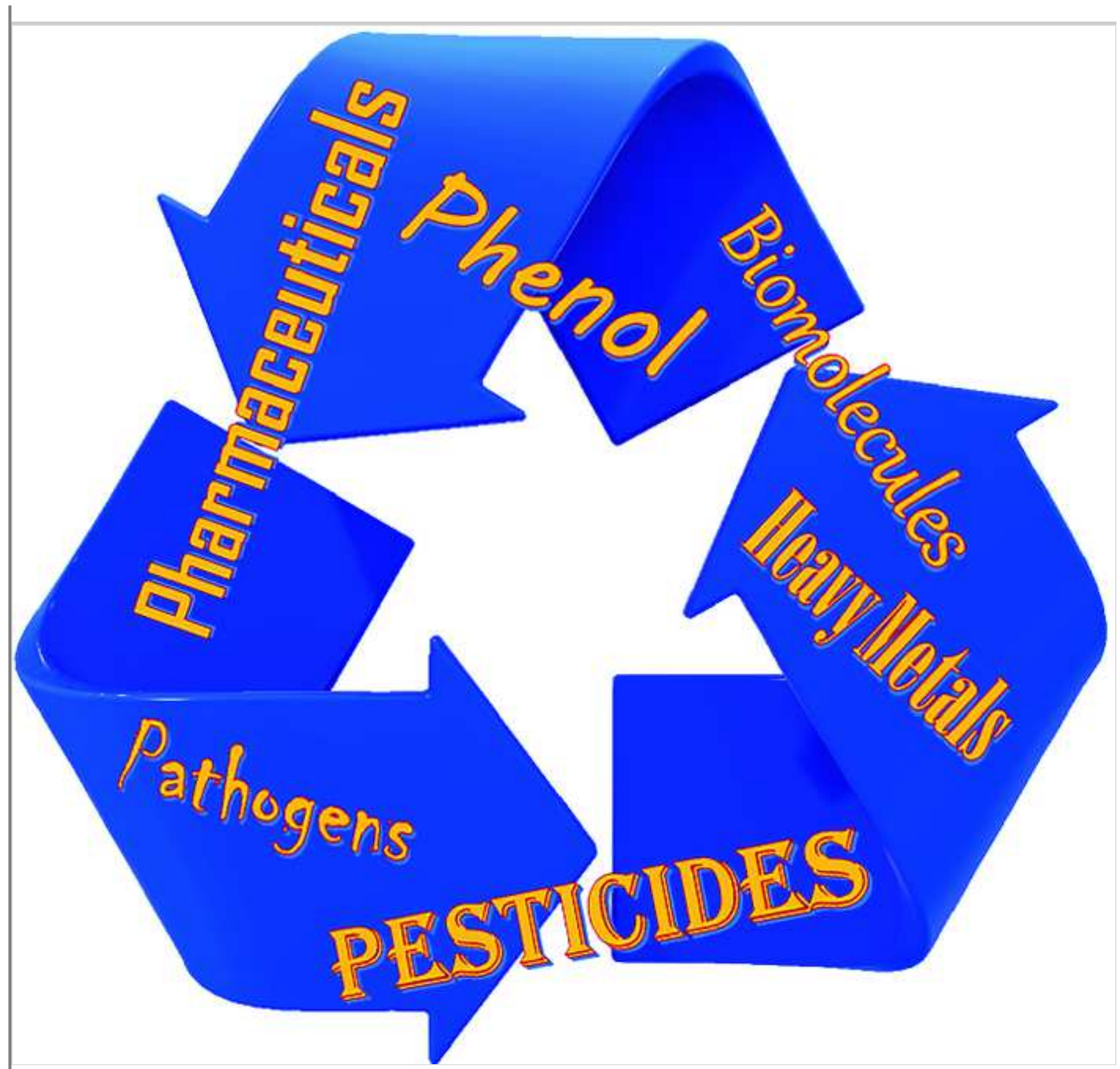




\subsection{Heavy Metals}

Metal ions, including heavy metals, existing in water above the recommended critical values turn out to be highly toxic [44]. Thus, control of their concentration in water is essential for human health and safety. In the last years, a few BDD sensors have been developed for fast, sensitive and stable identification and/or quantification of metal ions by means of electrochemical and bioelectrochemical techniques. Table 1 summarizes representative results for BDD-based sensors applied in metals environmental monitoring [45].

\section{Table 1}

Representative results for application of doped diamond-based sensors to metals environmental monitoring

\begin{tabular}{|c|c|c|c|c|c|}
\hline Metal & $\begin{array}{l}\text { Electrochemical } \\
\text { technique }\end{array}$ & $\begin{array}{l}\text { Model/real } \\
\text { system }\end{array}$ & Limit of detection (LOD) & Sensitivity & Ref. \\
\hline Arsenic & $\mathrm{CV}^{\mathrm{a}}$ & $\begin{array}{l}\text { Buffered } \\
\text { deionized water }\end{array}$ & $20 \mathrm{nM}$ & $93 \mathrm{nA} \mu \mathrm{M}^{-1} \mathrm{~cm}^{-2}$ & {$[46]$} \\
\hline \multirow{4}{*}{ Cadmium } & $\begin{array}{l}\text { Ultrasound assisted } \\
\text { SWASV }^{\mathrm{b}}\end{array}$ & $\begin{array}{l}\text { Buffered } \\
\text { deionized water }\end{array}$ & $1.0 \mu \mathrm{g} \mathrm{L}-1$ & - & [47] \\
\hline & SWASV $^{\mathrm{b}}$ & $\begin{array}{l}\text { Buffered } \\
\text { deionized water }\end{array}$ & $0.016 \mu \mathrm{g} \mathrm{L}^{-1}$ & - & {$[48]$} \\
\hline & $\mathrm{SWASV}^{\mathrm{b}}$ & $\begin{array}{l}\text { Buffered } \\
\text { deionized water }\end{array}$ & $10 \mathrm{ppb}$ & - & [49] \\
\hline & SWASV $^{\mathrm{b}}$ & $\begin{array}{l}\text { Buffered } \\
\text { deionized water }\end{array}$ & $10^{-9} \mathrm{M}$ & $3.78 \mu \mathrm{A} \mu \mathrm{M}^{-1}$ & {$[50]$} \\
\hline \multirow{5}{*}{ Lead } & $\mathrm{CV}^{\mathrm{a}}$ & Deionized water & $1.78 \mu \mathrm{g} \mathrm{L}^{-1}$ & - & {$[51]$} \\
\hline & $\mathrm{SWASV}^{\mathrm{b}}, \mathrm{LSV}^{\mathrm{d}}$ & Tap water & $2 \mathrm{nM}$ & - & {$[52]$} \\
\hline & $\mathrm{SWASV}^{\mathrm{b}}$ & Tap water & $0.3 \mu \mathrm{g} \mathrm{L}{ }^{-1}$ & - & {$[53]$} \\
\hline & SWASV $^{\mathrm{b}}$ & $\begin{array}{l}\text { Buffered } \\
\text { deionized water }\end{array}$ & $0.57 \mu \mathrm{g} \mathrm{L}^{-1}$ & $1.57 \mu \mathrm{A} \mu \mathrm{g} \mathrm{L}^{-1}$ & {$[54]$} \\
\hline & $\mathrm{SWASV}^{\mathrm{b}}, \mathrm{LSV}^{\mathrm{d}}$ & River sediment & $187.1 \mathrm{mg} \mathrm{kg}^{-1}$ & - & {$[55]$} \\
\hline Lead/Copper & $\mathrm{SWASV}^{\mathrm{b}}, \mathrm{LSV}^{\mathrm{d}}$ & Deionized water & $2.5 \times 10^{-6} \mathrm{M}-10^{-4} \mathrm{M}^{\mathrm{e}}$ & - & {$[56]$} \\
\hline
\end{tabular}

${ }^{\mathrm{a} C y c l i c}$ voltammetry; ${ }^{\mathrm{b}}$ square wave anodic stripping voltammetry; ${ }^{\mathrm{c}}$ differential pulse anodic stripping voltammetry; ${ }^{\mathrm{d}}$ linear sweep voltammetry; ${ }^{\mathrm{e}}$ response range 
lead detection [55]. Dragoe et al. [52] have performed lead detection in tap water with a LOD of $2 \mathrm{nM}$ and, similarly, Chooto et al. [53] proposed a method with which they obtained a LOD of $0.3 \mu \mathrm{g} \mathrm{L}$.

Prado et al. [56] studied the interaction between $\mathrm{Pb}$ and $\mathrm{Cu}$ during simultaneous detection by SWASV. An extra peak attributed to hydrogen evolution on copper was observed. The interaction between $\mathrm{Pb}$ and Cd during Differential pulse anodic stripping voltammetry (DPASV) analysis was investigated by Manivannan et al. [57] and their findings include LOD values of $0.25 \mu \mathrm{M}(\mathrm{Pb})$ and $0.31 \mu \mathrm{M}(\mathrm{Cd})$ but a slight increase of those values was verified when the two metals are present, explained by the proposed model based on 3D calibration curve to avoid cross-interference between these two metals. Sonthalia et al. [58] analyzed much more complex matrices in even more complex media such as lake, well and tap waters concluding that further optimization of the BDD electrode was necessary since the stripping peaks were rather broad and the intermetallic compound formation also needs to be addressed. Similarly, McGaw and Swain [59] compared the performance between a BDD electrode and that of $\mathrm{Hg}$-coated glassy carbon $(\mathrm{Hg}-\mathrm{GC})$ in a complex matrix containing $\mathrm{Pb} / \mathrm{Cd} / \mathrm{Ag} / \mathrm{Cu} / \mathrm{Zn}$. They concluded that BDD had a as good or superior performance to that for $\mathrm{Hg}-\mathrm{GC}$, also demonstrating that BDD lower sensitivity was not due to incomplete metal oxidation or metal phase detachment from its surface. Another complex system with $\mathrm{Zn}, \mathrm{Cd}, \mathrm{Pb}$ and $\mathrm{Cu}$ was investigated in buffered water samples and difficulties were encountered since copper caused a lot of interference with other metals becoming the major problem for the analysis [60]. Zhao et al. [61] reported on an in situ experiment for $\mathrm{Pb} / \mathrm{Cd} / \mathrm{Cu} / \mathrm{Zn}$ simultaneous detection in seawater. It was possible to effectively obtain repeatable results proving suitability of the BDD electrode for detection of heavy metals in seawater.

Applying the same sonoelectrochemical technique, Compton's group also reported on the improvement of silver detection [62]. Detection of trace amounts of radionuclides has been explored by de Sanoit et al. [63] in the design of an electrochemically assisted radiation BDD-based sensor. Direct alpha-particles counting, and alpha spectrometry were used to determine the electrodeposition of the actinides onto the BDD thin films with a LOD of 0.5 Bq L ${ }^{-1}$ a work in the process of being patented. Finally, a review on the major contribution of the French scientific academic community in the field of electrochemical sensors and electroanalytical methods within the last 20 years should also be mentioned [44].

As previously observed for several other analytical techniques commonly used in the determination of metals in complex matrices, the competition effect between the ions is a major drawback for selectivity. Nonetheless, BDD electrodes appear to mostly overcome specially because samples derivatization prior to analysis is not essential.

\subsection{Pesticides}

Pesticides are being extensively used in most sectors of agriculture, livestock or households and their toxicities have been assessed via different assays or using models such as in vitro, in vivo or in situ strategies. Mostly, pesticides are employed to incapacitate, prevent or even kill pest damage to plants. The major problem associated to such compounds is their accumulation environmental persistence. Moreover, there are still not enough devices or approaches to detect pesticides in aquatic media or a large-scale remedy to eliminate them [64]. This type of synthetic compounds can be classified according to their chemical nature and/or their functional application. Thus, pesticides can be subdivided in three groups: insecticides, herbicides and fungicides. For practical reasons, sensors based in BDD for detection of pesticides in water will be divided accordingly to those groups and presented in this sub-section.

As indicated by the name, fungicides are a group of pesticides designed to prevent or destroy parasitic fungi. To the best of our knowledge, we were only able to retrieve one reported work on BDD application for detection of a fungicide. In this work, Stankovich and Kalcher [65] reported on sensitive and selective quantification of ziram using an amperometric procedure with a limit of detection (LOD) estimated to be $2.7 \mathrm{nM}$. The method was then tested in two river water samples spiked with the contaminant and it showed good potential as an electroanalytical approach for ziram quantification. 
Herbicides are used to control or kill unwanted plants in agricultural crops. It should be noted that in most of the literature here presented, the detection methods include testing in specific but real water samples, or spiked ones if the contaminant is not present in the real system. Table 2 summarizes representative results for BDD-based sensors applied in pesticides environmental monitoring.

\section{Table 2}

Representative results for application of doped diamond-based sensors to pesticides environmental monitoring

\begin{tabular}{|c|c|c|c|c|c|}
\hline & Electrochemical technique & Model/real system & Limit of detection (LOD) & Sensitivity & Ref. \\
\hline \multicolumn{6}{|l|}{ Fungicide } \\
\hline Ziram & Flow injection amperometry & Buffered deionized water & $2 \mathrm{nM}$ & - & {$[65]$} \\
\hline \multicolumn{6}{|l|}{ Herbicide } \\
\hline Aniline & $\mathrm{LSV}^{\mathrm{a}}$ & Buffered deionized water & $5 \mu \mathrm{M}$ & $0.08 \mu \mathrm{A} \mu \mathrm{M}^{-1}$ & {$[66]$} \\
\hline Atrazine & Chronoamperometry & Buffered deionized water & $3.5 \mathrm{pM}$ & - & {$[67]$} \\
\hline Bentazone & $\mathrm{DPV}^{\mathrm{b}}, \mathrm{SWASV}^{\mathrm{c}}$ & Buffered deionized water & $1.2 \mu \mathrm{M}$ (DPV), $0.5 \mu \mathrm{M}$ (SWASV) & - & [68] \\
\hline Paraquat & SWASV $^{\mathrm{c}}$ & Buffered deionized water & $1.5 \times 10^{-9} \mathrm{~mol} \mathrm{~L}^{-1}$ & - & {$[69]$} \\
\hline Picloram & $\mathrm{DPV}^{\mathrm{b}}$ & Deionized water & $70 \mathrm{nmol} \mathrm{L}^{-1}$ & - & {$[70]$} \\
\hline Triclopyr & $\mathrm{DPV}^{\mathrm{b}}, \mathrm{SWASV}^{\mathrm{c}}$ & Tap and natural waters & $0.82 \mu \mathrm{M}(\mathrm{DPV}) ; 1.85 \mu \mathrm{M}(\mathrm{SWASV})$ & - & [71] \\
\hline \multicolumn{6}{|l|}{ Insecticide } \\
\hline Azamethiphos & $\mathrm{SWASV}^{\mathrm{c}}$ & Ground and river waters & $0.45 \mu \mathrm{M}$ & - & {$[72]$} \\
\hline Carbaryl & SWASV $^{\mathrm{c}}$ & Deionized water & $2.08 \mu \mathrm{M}$ & - & [73] \\
\hline Imidacloprid & $\mathrm{SWASV}^{\mathrm{c}}$ & Deionized water & $8.60 \mu \mathrm{M}$ & - & [74] \\
\hline Mancozeb & $\mathrm{PA}^{\mathrm{d}}$ & Buffered deionized water & $5.14 \times 10^{-7} \mathrm{~mol} \mathrm{~L}^{-1}$ & - & {$[75]$} \\
\hline Methomyl & $\mathrm{DPV}^{\mathrm{b}}, \mathrm{SWASV}^{\mathrm{c}}$ & Buffered deionized water & $1.2 \times 10^{-6} \mathrm{~mol} \mathrm{~L}^{-1}(\mathrm{DPV}) ; 1.9 \times 10^{-5} \mathrm{~mol} \mathrm{~L}^{-1}(\mathrm{SWASV})$ & - & {$[76]$} \\
\hline Pirimicarb & $\mathrm{DPV}^{\mathrm{b}}, \mathrm{SWASV}^{\mathrm{c}}$ & Buffered deionized water & $1.24 \mu \mathrm{M}(\mathrm{DPV})$ & - & {$[77]$} \\
\hline
\end{tabular}


carbon spheres for the detection of organophostate pesticides such as chlorpyrifos and methyl parathion. The LOD value found for methyl parathion was $1.29 \times$ $10^{-13}$ and $4.9 \times 10^{-13} \mathrm{M}$ for chlorpyrifos.

It appears that, when comparing DPV and SWASV electrochemical techniques, the former gives lower limits of detection for this pollutants group.

Nevertheless, one should bear in mind that the BDD electrode physicochemical properties play a major role in the detection and quantification process.

\subsection{Phenol and Derivatives}

Phenol and its derivatives, particularly phenolic compounds, are an organic compounds family with a characteristic hydroxyl group attached to an aromatic ring These compounds are common by-products of the industrial processes of petroleum, paper, plastics or drugs, but also used as food antioxidants. However, these are often discharged along with effluents from the industry and considered as water pollutants [81].

Lv et al. [82] used an as-grown and nanograss array of BDD electrodes to electrochemically detect catechol in buffered deionized water. A LOD of about 2.8 and 1.3 $\mu \mathrm{M}$ were found for the as-grown BDD electrode and the nanograss array BDD electrode, respectively, and demonstrating that the nanograss array BDD was more efficient towards catechol detection. A fast and direct determination of a phenolic antioxidant used in biodiesel, butylated hydroxyanisole (BHA), by batch injection analysis with amperometric detection was proposed by Tormin et al. [83]. It was one of the first works indicating the application of BDD

electrodes for detection of compounds in non-aqueous electrolytes. The LOD obtained for the analyte was $100 \mathrm{ng}$ of BHA per g of biodiesel. Janegitz et al. [84] have reported on a tyrosinase-based biosensor for phenol determination using a BDD electrode with gold nanoparticles electrodeposited onto the surface. The obtained results using SWASV led to a LOD of $0.07 \mu \mathrm{M}$ with the sensor exhibiting good sensitivity, stability and reproducibility. A BDD anodically pretreated electrode was tested for 4-chloro-3-methylphenol detection, in the absence and presence of a cationic surfactant, mimicking disinfectant or preservative liquid media [85]. Different electrochemical techniques like CV, direct current voltammetry (DCV), differential pulse voltammetry (DPV) or SWASV were used in this study with LOD values of around $0.85,0.46$ and $0.34 \mu \mathrm{M}$ for DCV, DPV and SWASV, respectively. Moreover, DPV studies showed that the relationship between the boron content and LOD was not linear. Another investigation of electrochemical behavior of 4-nitrophenyl triazole labeled nucleosides at BDD electrode by means of voltammetric techniques [86]. There was a highly stable response of the -NHOH/-NO redox couple and strong adhesion of the tested powerfully adsorbing nucleoside conjugates to the BDD surface was verified.

\subsection{Pharmaceutical Compounds}

The environmental impact of both human and veterinary pharmaceuticals has dramatically increased in the last decade. Unfortunately, only now the risks are slightly better understood but it still is vital to manage them. As with any other type of pollutant, awareness is not enough, and immediate actions are required. Uncontrolled entrance of pharmaceutical compounds in the environment takes place during their production, consumption and disposal. Again, the fate of most pollutants ends in the aquatic environment: antibiotics and analgesic/anti-inflammatories mainly present in surface water and wastewater; high levels of active pharmaceutical ingredients, excreted by human patients or improper disposal; and increasing municipal discharges of wastewater onto the oceans with consequent impact in marine systems and human health. Thus, individual identification and determination of pharmaceuticals in aquatic environment is crucial as well as those of drug mixtures since there are already evidence that the aggregate toxicity is higher [87, 88].

In this sub-section, representative reported works on BDD thin films applied for the detection and quantification for pharmaceutical compounds are presented and separated according to their physiological system of action. Thus, the active substances will be mainly divided into antimicrobial drugs, drugs affecting the cardiovascular, central nervous, digestive and reproductive/endocrine systems as well as drugs with impact on the skeletal and soft muscles [89]. 
Antimicrobial drugs are used in the prevention or treatment of disease caused by bacteria, viruses or fungi amongst others. Antibiotics such as Cephalexin [90], Enrofloxacin [91], Levofloxacin [92], Metronidazole [93] and Penicillin V [94] have been identified and determined by several electrochemical techniques like SWASV and DPV, using BDD electrodes. The latter showed good limits of detection in buffered water samples and the presence of interferents was also evacuated. After validation of the method experimental parameters, electroanalysis of real water samples was carried out. If case of absence of the analyte, the real samples were spiked. Table 3 resumes some of the findings in reported works for BDD electrodes used in identification and quantification of pharmaceutical compounds.

\section{Table 3}

Representative results for application of doped diamond-based sensors to pharmaceutical compounds environmental monitoring

\begin{tabular}{|c|c|c|c|c|}
\hline System & Electrochemical technique & Real system & Limit of detection (LOD) (model system) & Ref. \\
\hline \multicolumn{5}{|l|}{ Antimicrobial } \\
\hline Cephalexin & SWASV$^{\mathrm{a}}, \mathrm{DPV}^{\mathrm{b}}$ & River water & $34.74 \mathrm{ng} \mathrm{L}^{-1}$ & {$[90]$} \\
\hline Enrofloxacin & SWASVa & Urine & $0.0057 \mu \mathrm{g} \mathrm{L}^{-1}$ & {$[91]$} \\
\hline Levofloxacin & $\mathrm{SWASV}^{\mathrm{a}}, \mathrm{CV}^{\mathrm{c}}$ & Urine/Serum & $10.01 \mu \mathrm{g} \mathrm{L}^{-1}(\mathrm{CV}), 2.88 \mu \mathrm{g} \mathrm{L}^{-1}(\mathrm{SWASV})$ & {$[92]$} \\
\hline Metronidazole & $\mathrm{SWASV}^{\mathrm{a}}, \mathrm{CV}^{\mathrm{c}}$ & Urine & $0.065 \mu \mathrm{mol} \mathrm{L}-1$ & {$[93]$} \\
\hline Penicillin V & $\mathrm{DPV}^{\mathrm{b}}$ & Deionized water & $0.25 \mu \mathrm{M}$ & {$[94]$} \\
\hline Penicillin V/Paracetamol & SWASV$^{1}$ & Urine & 0.21 and $0.32 \mu \mathrm{M}$ & {$[95]$} \\
\hline $\begin{array}{l}\text { Sulfamethoxazole } \\
\text { Trimethoprim } \\
\text { Phenazopyridine }\end{array}$ & MPA $^{\mathrm{d}}$ & Deionized water & $\begin{array}{l}0.20 \mathrm{mg} \mathrm{L}^{-1} \\
0.15 \mathrm{mg} \mathrm{L}^{-1} \\
0.05 \mathrm{mg} \mathrm{L}^{-1}\end{array}$ & {$[96]$} \\
\hline \multicolumn{5}{|l|}{ Cardiovascular } \\
\hline Amlodipine & $\mathrm{DPV}^{\mathrm{b}}$ & Urine & $0.07 \mu \mathrm{M}$ & {$[97]$} \\
\hline Furosemide & SWASV $^{\mathrm{a}}$ & Urine/Serum & $3.0 \times 10^{-7} \mathrm{~mol} \mathrm{~L}^{-1}$ & {$[98]$} \\
\hline Pindolol & $\mathrm{DPV}^{\mathrm{b}}$ & Urine/Serum & $26 \mathrm{nmol} \mathrm{L}^{-1}$ & {$[99]$} \\
\hline Rosuvastatin calcium & SWASV$^{1}$ & Urine/Serum & $1.04 \mathrm{mg} \mathrm{L}^{-1}$ & {$[100]$} \\
\hline
\end{tabular}

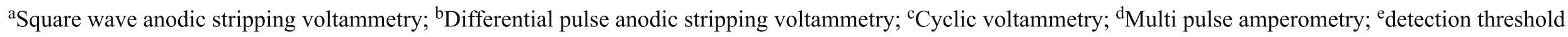




\begin{tabular}{|c|c|c|c|c|}
\hline System & Electrochemical technique & Real system & Limit of detection (LOD) (model system) & Ref. \\
\hline Amlodipine/valsartan & SWASVa & Urine & 0.0764 and $0.193 \mu \mathrm{mol} \mathrm{L}^{-1}$ & {$[101]$} \\
\hline Hydrochlorothiazide/valsartan & SWASV $^{\mathrm{a}}$ & Deionized water & 0.639 and $0.935 \mu \mathrm{mol} \mathrm{L}^{-1}$ & [102] \\
\hline Hydrochlorothiazide/Enalapril & $\mathrm{MPA}^{\mathrm{d}}$ & Deionized water & 0.20 and $0.01 \mu \mathrm{mol} \mathrm{L}^{-1}$ & [103] \\
\hline Hydrochlorothiazide/captopril & $\mathrm{MPA}^{\mathrm{d}}$ & - & 0.27 and $0.14 \mu \mathrm{mol} \mathrm{L}^{-1}$ & {$[104]$} \\
\hline Hydrochlorothiazide/metoprolol & SWASV $^{\mathrm{a}}, \mathrm{DPV}^{\mathrm{b}}$ & Urine & $0.376 \mu \mathrm{mol} \mathrm{L}^{-1}$ and $0.077 \mu \mathrm{mol} \mathrm{L}^{-1}(\mathrm{DPV})$ & {$[105]$} \\
\hline $\begin{array}{l}\text { Amlodipine besylate (AML) } \\
\text { Amiloride hydrochloride (AMI) } \\
\text { Hydrochlorothiazide (HCTZ) } \\
\text { Atenolol (ATN) }\end{array}$ & SWASV $^{\mathrm{a}}$ & Tap water/Urine & $\begin{array}{l}0.30 \mu \mathrm{mol} \mathrm{L}-1 \\
0.09 \mu \mathrm{mol} \mathrm{L}^{-1} \\
0.08 \mu \mathrm{mol} \mathrm{L}^{-1} \\
0.06 \mu \mathrm{mol} \mathrm{L}^{-1}\end{array}$ & {$[106]$} \\
\hline \multicolumn{5}{|l|}{ Central nervous system } \\
\hline Ibuprofen & SWASV $^{\mathrm{a}}, \mathrm{DPV}^{\mathrm{b}}$ & Urine & $4.1 \times 10^{-7} \mathrm{~mol} \mathrm{~L}^{-1}(\mathrm{DPV}), 9.3 \times 10^{-7} \mathrm{~mol} \mathrm{~L}^{-1}(\mathrm{SWASV})$ & {$[107]$} \\
\hline Imipramine & SWASV & Deionized water & $4.35 \times 10^{-7} \mathrm{~mol} \mathrm{~L}^{-1}$ & {$[108]$} \\
\hline Naphazoline & SWASV $^{\mathrm{a}}$ & - & $0.04 \mu \mathrm{mol} \mathrm{L}-1$ & {$[109]$} \\
\hline Nicotine & DPV & Deionized water & $0.04 \mu \mathrm{M}$ & [110] \\
\hline Sibutramine & SWASV $^{\mathrm{a}}$ & Deionized water & $0.08-1.94 \mathrm{mg} \mathrm{L}^{-1}$ & {$[111]$} \\
\hline Alprazolam/Bromazepam & $\mathrm{DPV}^{\mathrm{b}}$ & Deionized water & $6.4 \times 10^{-7}$ and $3.1 \times 10^{-7} \mathrm{~mol} \mathrm{~L}^{-1}$ & {$[112]$} \\
\hline \multicolumn{5}{|l|}{ Digestive } \\
\hline Omeprazole & $\mathrm{CV}^{\mathrm{c}}$ & Deionized water & $9 \mathrm{nmol} \mathrm{L}^{-1}$ & {$[113]$} \\
\hline $\begin{array}{l}\text { Diphenhydramine } \\
\text { 8-Chlorotheophylline } \\
\text { Pyridoxine }\end{array}$ & Amperometry & Deionized water & $\begin{array}{l}0.60 \mu \mathrm{mol} \mathrm{L}-1 \\
0.19 \mu \mathrm{mol} \mathrm{L} \\
0.54 \mu \mathrm{mol} \mathrm{L}\end{array}$ & [114] \\
\hline \multicolumn{5}{|l|}{ Reproductive/endocrine } \\
\hline Tadalafil & SWASVa & Deionized water & $19.5 \mathrm{nmol} \mathrm{L}^{-1}$ & {$[115]$} \\
\hline
\end{tabular}

${ }^{\text {aS }}$ quare wave anodic stripping voltammetry; ${ }^{\mathrm{b}}$ Differential pulse anodic stripping voltammetry; ${ }^{\mathrm{c}}$ Cyclic voltammetry; ${ }^{\mathrm{d}}$ Multi pulse amperometry; ${ }^{\mathrm{e}} \mathrm{detection}$ threshold 


\begin{tabular}{|c|c|c|c|c|}
\hline System & Electrochemical technique & Real system & Limit of detection (LOD) (model system) & Ref. \\
\hline \multicolumn{5}{|l|}{ Skeletal muscles } \\
\hline Rapamycin & $\mathrm{DPV}^{\mathrm{b}}$ & Urine & $0.22 \mu \mathrm{M}$ & [116] \\
\hline Leucovorin & $\mathrm{DPV}^{\mathrm{b}}$ & Urine & $6.7 \times 10^{-8} \mathrm{~mol} \mathrm{~L}^{-1}$ & {$[117]$} \\
\hline \multicolumn{5}{|l|}{ Soft muscles } \\
\hline Tramadol & SWASV $^{\mathrm{a}}$ & Urine & $0.004 \mu \mathrm{M}$ & [118] \\
\hline Tramadol/Acetaminophen & $\mathrm{MPA}^{\mathrm{d}}$ & Urine & 0.04 and $0.03 \mu \mathrm{M}$ & [119] \\
\hline
\end{tabular}

${ }^{\text {a}}$ Square wave anodic stripping voltammetry; ${ }^{\mathrm{b}}$ Differential pulse anodic stripping voltammetry; ${ }^{\mathrm{c}} \mathrm{Cyclic}$ voltammetry; ${ }^{\mathrm{d}} \mathrm{Multi}$ pulse amperometry; ${ }^{\mathrm{e}} \mathrm{detection}$ threshold

Simultaneous detection of Penicillin V and Paracetamol was reported by Švorc et al. [95] finding good limits of detection for both analytes and obtaining successful selectivity with no need to chemical or electrochemical modification of the BDD electrode. Pereira et al. [96] developed a fast batch injection analysis method for simultaneous determination of Phenazopyridine, Sulfamethoxazole, and Trimethoprim. The analysis method was efficient and selective towards the three antibiotics with the major advantage of reduced analysis time and probability of the batch injection system.

Cardiovascular medication is used in cardiovascular diseases including hypertension or atherosclerosis and drugs affecting blood may also be comprised such as anticoagulants. Amlodipine [97], Furosemide [98] and Pindolol [99] are examples of anti-hypertensive drugs which have been detected by DPV and SWASV using BDD electrodes, showing very good limits of detection in buffered water samples and preserving their selectivity in the presence of interferents. Rosuvastatin calcium reduces low-density lipoprotein (LDL) cholesterol in blood and it was determined by DVP and SWASV with low LOD of 1.04 mg L ${ }^{-1}$ Binary systems have also been investigated [101], particularly with Hydrochlorothiazide [102-105]. These studies have showed that the applied methods of analysis were successful towards quantification and selective identification of the analytes, with low limits of detection and effective application in real systems like urine or human serum. A quaternary system containing amlodipine besylate, amiloride hydrochloride, hydrochlorothiazide, and atenolol [106]. An anodically pre-treated BDD electrode was employed in SWASV with very well-resolved and reproducible oxidative peaks demonstrating that coupling a BDD electrode and the SWASV technique result in an advanced electroanalytical platform with effective application in water media systems.

Central nervous system drugs include anesthetics and psychiatric drugs that influence neurotransmitters or behavior like antidepressants or antianxiety agents. Ibuprofen [107], Imipramine [108], Naphazoline [109], Nicotine [110] and Sibutramine [111] have been determined using BDD electrodes and DPV or SWASV electrochemical techniques. The proposed methods of analysis provided good LOD values and had effective application in real aquatic systems. A mixture between Alprazolam/Bromazepam [112] was also investigated and quite good limits of detection were found for each of the analytes, $6.4 \times 10^{-7}$ mol $\mathrm{L}^{-1}$ and $3.1 \times 10^{-7} \mathrm{~mol} \mathrm{~L}^{-1}$, respectively.

BDD thin films have also been successfully used in the detection and quantification of drugs affecting the digestive system altering its movements or the gastrointestinal fluids such as antidiarrheal drugs, laxatives or antacids, including proton pump inhibitors like Omeprazole [113], amongst others [114]; 
|reproductive/endocrine system drugs include to treat erectile disfunction Tadalafil [115]; skeletal muscles drugs used for treatment of diseases related to the spinal cord and like the immunosuppressor Rapamycin [116] or a cancer treatment drug like Leucovorin [117]; and soft muscles drugs affecting the internal body organs muscles like Tramadol [118] and Acetaminophen [119].

\subsection{Pathogens}

As previously described, diamond is inert and innocuous towards bacillus, bacteria and other pathogenic microorganisms. Marciano et al. [120] has reported on diamond-like carbon, a metastable form of amorphous carbon, films produced with high deposition rates showing antimicrobial activity towards Escherichia coli; and synergism between nanocrystalline diamond and graphene treated with fluorine plasma showed antibacterial activity [121]. A biosensor based on BDD electrode poised at a positive potential has been exploited for the detection of $E$. coli contamination in artificially spiked samples of meat, milk and tap water [122]. Through a specific enzyme, $\beta$-galactosidase, after a total analysis time of less than $1.5 \mathrm{~h}$, the detection limit of $4 \times 10^{4}$ cells $/ \mathrm{mL}$ was obtained. Deepultraviolet (DUV) light sources are being investigated on sterilization of $E$. coli since direct irradiation results in a significant inhibition of growth of such microorganisms [123]. Thus, DUV diamond light emitting diodes (LEDs) may become a valuable germicidal light source.

BDD electrodes (DiaCell ${ }^{\circledR}$ technology) have been successfully tested against Legionella pneumophila infection in several tap waters [124]. To the best of our knowledge, we were not able to find reported work using BDD electrodes for detection of any Bacillus type. As it will be seen in Sect. 4, BDD electrodes demonstrate effective application in environmental remediation via water electrolysis and/or electroxidation.

\subsection{Biomolecules}

Environmental consciousness has also to do with balance and equilibrium in the ecosystem. Pollutants with anthropogenic origin are the major concerns because nature always had self-management skills. In this small section, we report on a few biomolecules with increasing toxicological significance. This is mainly due to their use in a wide range of sources including medicinal purposes acting as hallucinogenic, such as $\beta$-carboline alkaloids, also produced in cigarette smoke [125]. Sensitive determination of harmaline was carried out using a BDD electrode in DPV and SWASV techniques with LOD of 0.08 and $0.2 \mu$ M, respectively. Two other biomolecules of increasing interest like vanillin (VAN) and caffeine (CAF) were simultaneously determined using an anodically pretreated BDD electrode [126]. SWASV studies provided simultaneous determination of VAN and CAF, with detection limits of 0.234 and $0.071 \mu \mathrm{M}$, respectively.

\section{Environmental Remediation}

The previous section summarized some of recent work developed around the application of boron-doped diamond (BDD) thin films for environmental monitoring, particularly in aquatic media. The real efficiency of BDD as an electrode providing fast, straightforward, sensitive, reproducible and robust electrochemical analysis of numerous pollutants has been demonstrated. BDD thin films are rather versatile materials due to their unique properties and their electrochemical excellency, they have been further explored in electroxidation of contaminants. This confers BDD thin films the ability to work simultaneously as environmental sensors and cleaners. This important aspect and functionality of BDD thin films is briefly explored in this section.

\subsection{Advanced Electrochemical Oxidation Processes}


The development of efficient, simple and cost-effective processes to remove and/or destroy pollutants is a priority. Most conventional wastewater treatment plants are not prepared to efficiently eliminate all types of contaminants becoming another source of environmental pollution into natural waters, particularly the ocean. Subsequently, the best option is to eliminate or preferably extinguish the pollutants before being discharged. Advanced oxidation processes are an available technology to effectively perform that purpose. It is based on in situ production of strong oxidants like hydroxyl radicals which can oxidize any organic contaminant until its final mineralization. These hydroxyl radicals can be produced via chemical means like the Fenton process, photochemical methods (heterogeneous catalysis, UV photolysis and photo-Fenton) or electrochemically. The latter are the most recent advanced oxidation technology which include electroxidation and electro-Fenton processes.

Electroxidation is based on anodic oxidation and BDD thin films have been extensively investigated for this purpose already with effective application in this type of green technology. Additionally, BDD thin films are robust and stable enough to support electrical potentials above that of water electrolysis. Thus, hydroxyls are produced from water splitting and BDD also performs mineralization of such organic pollutants. In fact, BDD thin films have been tested in real systems such as wastewater effluents or winery wastewater, amongst others [127-132].

The electro-Fenton process is based on Fenton's reaction combined with electrochemistry which, ultimately, originate further hydroxyl species enough to also mineralize the contaminants. Once more, BDD thin films are being investigated as cathode or anode electrodes in the electro-Fenton process [133-135].

BDD thin films are an all-purpose nanostructured material with wide and effective application in environmental science.

\section{Concluding Remarks}

The main objective of this chapter is to provide the reader the current state of scientific research around diamond-based nanostructured materials used as electrochemical sensors for aquatic contaminants. CVD diamond can be produced with variable morphologies and with different surface chemical terminations which, in their turn, will determine the electrochemical performance. This versatility naturally enables tailoring of their properties towards all sorts of purposes. Application of these valuable materials in electrochemical sensing and analysis has been clearly demonstrated due to their remarkable electrochemical capabilities as verified by the immense amount of work that has been carried out on the subject. Diamond displays most of the requirements to be considered the elected material to be employed for a certain sensing application. As an electrode for electrochemical purposes, its performance is as good as that of noble and expensive metals and is commercially available. Moreover, as an electrochemical sensor it provides superior results than those delivered by conventional analytical techniques.

Nevertheless, not all is perfect in the diamond world. There also some drawbacks and challenges to overcome. Its effective application in environmental remediation will always be contested by emerging contaminants or merely by its cost or availability. Simultaneous sensing of numerous contaminants with similar redox behavior with in situ and at real time suitable signal deconvolution is not straightforward. The same applies to miniaturization and portability of the sensor devices or remote access to them.

Still, all points out to a positive future for synthetic diamond-based nanostructured materials and their real application as sensors in environmental monitoring and as massive cleaning tools in environmental remediation. 


\section{References}

1. Daily, H.E.: Ecol. Econ. 2, 1-6 (1990)

2. Arregui, F.J.: Sensors Based on Nanostructured Materials. Springer, Berlin (2009)

3. Hussain, C.M., Kharisov, B. (eds.): Advanced Environmental Analysis. Royal Society of Chemistry, Cambridge (2016)

4. Li, M., Gou, H., Al-Ogaidi, I., Wu, N., Sustain, A.C.S.: Chem. Eng. 1, 713-723 (2013)

5. Singh, R.C., Singh, M.P., Virk, H.S.: Solid State Phenom. 201, 131-158 (2013)

6. Justino, C.I.L., Duarte, A.C., Rocha-Santos, T.A.P.: Sensors (Switzerland) 17 (2017)

7. Hernandez-Vargas, G., Sosa-Hernández, J.E., Saldarriaga-Hernandez, S., Villalba-Rodríguez, A.M., Parra-Saldivar, R., Iqbal, H.M.N.: Biosensors 8, 1-21 (2018)

8. Deng, Y.: Semiconducting Metal Oxides for Gas Sensing (2019)

9. A. Nanomaterials, Advanced Environmental Analysis (2016)

10. Andrade, F.J., Blondeau, P., Macho, S., Riu, J., Rius, F.X.: Encycl. Anal. Chem. 1-17 (2014)

11. Luo, X., Yang, J.: J. Sensors (2019)

12. Rujuan, Z., Kelin, G., Zuping, Z., Yanxia, W., Jiezhou, L., Zhilin, X., Hongtu, L., Zhiqiang, W., Jian, Y., Guien, Z., Changsui, W.: Chin. Phys. Lett. 7, 445448 (1990)

13. Swartzlander, A.B., Nelson, A.J., Woollam, J.A.: J. Mater. Res. 3, 1397-1403 (1988)

14. Mortet, V., Hubicka, Z., Vorlicek, V., Jurek, K., Rosa, J., Vanecek, M.: Phys. Status Solidi Appl. Res. 201, 2425-2431 (2004)

15. Tsai, W., Reynolds, G.J., Hikido, S., Cooper, C.B.: Appl. Phys. Lett. 60, 1444-1446 (1992)

16. Haubner, R., Lux, B.: Diam. Relat. Mater. 2, 1277-1294 (1993) 
17. Brillas, E., Martínez-Huitle, C.A.: Synthetic Diamond Films: Preparation, Electrochemistry, Characterization, and Applications (2011)

18. Mildren, R.P., Rabeau, J.R.: Optical Engineering of Diamond (2013)

19. Yang, N., Foord, J.S., Jiang, X.: Carbon N. Y. 99, 90-110 (2016)

20. Yu, Y., Zhou, Y., Wu, L., Zhi, J.: Int. J. Electrochem. 2012, 1-10 (2012)

21. Yang, N., Yu, S., MacPherson, J.V., Einaga, Y., Zhao, H., Zhao, G., Swain, G.M., Jiang, X.: Chem. Soc. Rev. 48, 157-204 (2019)

22. Garrett, D.J., Tong, W., Simpson, D.A., Meffin, H.: Carbon N. Y. 102, 437-454 (2016)

23. J. R. Soc. Interface 14 (2017)

24. Iwaki, M., Sato, S., Takahashi, K., Sakairi, H.: Nucl. Instruments Methods Phys. Res. 209-210, 1129-1133 (1983)

25. Pelskov, Y.V., Sakharova, A.Y., Krotova, M.D., Bouilov, L.L., Spitsyn, B.V.: J. Electroanal. Chem. 228, 19-27 (1987)

26. Patel, K., Hashimoto, K., Fujishima, A.: J. Photochem. Photobiol. A Chem. 65, 419-429 (1992)

27. Macpherson, J.V.: Phys. Chem. Chem. Phys. 17, 2935-2949 (2015)

28. Garcia-Segura, S., Vieira Dos Santos, E., Martínez-Huitle, C.A.: Electrochem. Commun. 59, $52-55$ (2015)

29. Ayres, Z.J., Newland, J.C., Newton, M.E., Mandal, S., Williams, O.A., Macpherson, J.V.: Carbon N. Y. 121, 434-442 (2017)

30. Schwarzová-Pecková, K., Vosáhlová, J., Barek, J., Šloufová, I., Pavlova, E., Petrák, V., Zavázalová, J.: Electrochim. Acta 243, 170-182 (2017)

31. Kavan, L., Vlckova Zivcova, Z., Petrak, V., Frank, O., Janda, P., Tarabkova, H., Nesladek, M., Mortet, V.: Electrochim. Acta 179, 626-636 (2015)

32. Safaie, P., Eshaghi, A., Bakhshi, S.R.: J. Non. Cryst. Solids 471, 410-414 (2017)

33. Hébert, C., Mazellier, J.P., Scorsone, E., Mermoux, M., Bergonzo, P.: Carbon N. Y. 71, 27-33 (2014)

34. Lee, S.K., Song, M.J., Lim, D.S.: J. Electroanal. Chem. 820, 140-145 (2018)

35. Vlčková Živcová, Z., Mortet, V., Taylor, A., Zukal, A., Frank, O., Kavan, L.: Diam. Relat. Mater. 87, 61-69 (2018)

https://eproofing.springer.com/books_v2/printpage.php?token=mAbwH_uJrJQhFImXZR_mi3PTj8nimQQrBSL_ns3HgcU 
36. Mahé, E., Devilliers, D., Dardoize, F.: Talanta 132, 641-647 (2015)

37. Rusinek, C.A., Becker, M.F., Rechenberg, R., Schuelke, T.: Electrochem. Commun. 73, 10-14 (2016)

38. Piret, G., Hébert, C., Mazellier, J.P., Rousseau, L., Scorsone, E., Cottance, M., Lissorgues, G., Heuschkel, M.O., Picaud, S., Bergonzo, P., Yvert, B.: Biomaterials 53, 173-183 (2015)

39. Halpern, J.M., Cullins, M.J., Chiel, H.J., Martin, H.B.: Diam. Relat. Mater. 19, 178-181 (2010)

40. Read, T.L., Cobb, S.J., Macpherson, J.V.: ACS Sens. 4, 756-763 (2019)

41. Forsberg, P., Jorge, E.O., Nyholm, L., Nikolajeff, F., Karlsson, M.: Diam. Relat. Mater. 20, 1121-1124 (2011)

42. Chartres, N., Bero, L.A., Norris, S.L.: Environ. Int. 123, 231-239 (2019)

43. Ginige, T.: T.A. Convention, Advanced Environmental (2011)

44. Pujol, L., Evrard, D., Groenen-Serrano, K., Freyssinier, M., Ruffien-Cizsak, A., Gros, P.: Front. Chem. 2, 1-24 (2014)

45. Gumpu, M.B., Sethuraman, S., Krishnan, U.M., Rayappan, J.B.B.: Sens. Actuators B Chem. 213, 515-533 (2015)

46. Ivandini, T.A., Sato, R., Makide, Y., Fujishima, A., Einaga, Y.: Anal. Chem. 78, 6291-6298 (2006)

47. Zhang, T., Li, C., Mao, B., An, Y.: Ionics (Kiel) 21, 1761-1769 (2015)

48. Sardinha, A.F., Arantes, T.M., Cristovan, F.H., Ferreira, N.G.: Thin Solid Films 625, 70-80 (2017)

49. Fierro, S., Watanabe, T., Akai, K., Yamanuki, M., Einaga, Y.: J. Electrochem. Soc. 158, F173 (2011)

50. Banks, C.E., Hyde, M.E., Tomčíc, P., Jacobs, R., Compton, R.G.: Talanta 62, 279-286 (2004)

51. Peilin, Z., Jianzhong, Z., Shenzhong, Y., Xikang, Z., Guoxiong, Z.: Anal. Bioanal. Chem. 353, 171-173 (1995)

52. Dragoe, D., Spătaru, N., Kawasaki, R., Manivannan, A., Spătaru, T., Tryk, D.A., Fujishima, A.: Electrochim. Acta 51, 2437-2441 (2006)

53. Innuphat, C., Chooto, P.: ScienceAsia 43, 33-41 (2017) 
54. Arantes, T.M., Sardinha, A., Baldan, M.R., Cristovan, F.H., Ferreira, N.G.: Talanta 128, 132-140 (2014)

55. Saterlay, A.J., Agra-Gutiérrez, C., Taylor, M.P., Marken, F., Compton, R.G.: Electroanalysis 11, 1083-1088 (1999)

56. Prado, C., Wilkins, S.J., Marken, F., Compton, R.G.: Electroanalysis 14, 262-272 (2002)

57. Manivannan, A., Kawasaki, R., Tryk, D.A., Fujishima, A.: Electrochim. Acta 49, 3313-3318 (2004)

58. Sonthalia, P., McGaw, E., Show, Y., Swain, G.M.: Anal. Chim. Acta 522, 35-44 (2004)

59. McGaw, E.A., Swain, G.M.: Anal. Chim. Acta 575, 180-189 (2006)

60. El Tall, O., Jaffrezic-Renault, N., Sigaud, M., Vittori, O.: Electroanalysis 19, 1152-1159 (2007)

61. Zhao, B., Ren, Y., Li, J., Yu, X., Zhang, J.: Surf. Rev. Lett. 1850179, 1-9 (2018)

62. Saterlay, A.J., Marken, F., Foord, J.S., Compton, R.G.: Talanta 53, 403-415 (2000)

63. de Sanoit, J., Quang Tran, T., Pomorski, M., Pierre, S., Mer-Calfati, C., Bergonzo, P.: Appl. Radiat. Isot. 80, 32-41 (2013)

64. Prieto Garcia, F., Cortés Ascencio, S.Y., Oyarzun, J.C.G., Hernandez, A.C., Alavarado, P.V.: J. Res. Environ. Sci. Toxicol. 1, 2315-5698 (2012)

65. Stanković, D.M., Kalcher, K.: Sens. Actuators B Chem. 233, 144-147 (2016)

66. Spătaru, T., Spătaru, N., Fujishima, A.: Talanta 73, 404-406 (2007)

67. Medina-Sánchez, M., Mayorga-Martinez, C.C., Watanabe, T., Ivandini, T.A., Honda, Y., Pino, F., Nakata, A., Fujishima, A., Einaga, Y., Merkoçi, A.: Biosens. Bioelectron. 75, 365-374 (2016)

68. Jevtić, S., Stefanović, A., Stanković, D.M., Pergal, M.V., Ivanović, A.T., Jokić, A., Petković, B.B.: Diam. Relat. Mater. 81, 133-137 (2018)

69. Tyszczuk-Rotko, K., Bęczkowska, I., Nosal-Wiercińska, A.: Diam. Relat. Mater. 50, 86-90 (2014)

70. Bandžuchova, L., Švorc, L., Sochr, J., Svítkova, J., Chýlkova, J.: Electrochim. Acta 111, 242-249 (2013)

71. Janikova-Bandzuchova, L., Šelešovská, R., Schwarzová-Pecková, K., Chýlková, J.: Electrochim. Acta 154, 421-429 (2015) 
72. Vukojević, V., Djurdjić, S., Jevtić, S., Pergal, M.V., Marković, A., Mutić, J., Petković, B.B., Stanković, D.M.: Int. J. Environ. Anal. Chem. 98, 1175-1185 (2018)

73. Garbellini, G.S., Avaca, L.A., Salazar-Banda, G.R.: Quim. Nov. 33, 2261-2265 (2010)

74. Ben Brahim, M., Belhadj Ammar, H., Abdelhédi, R., Samet, Y.: Chinese Chem. Lett. 27, 666-672 (2016)

75. Silva, R.A.G., Silva, L.A.J., Munoz, R.A.A., Richter, E.M., Oliveira, A.C.: J. Electroanal. Chem. 733, 85-90 (2014)

76. Costa, D.J.E., Santos, J.C.S., Sanches-Brandão, F.A.C., Ribeiro, W.F., Salazar-Banda, G.R., Araujo, M.C.U.: J. Electroanal. Chem. 789, 100-107 (2017)

77. Selva, T.M.G., de Araujo, W.R., Bacil, R.P., Paixão, T.R.L.C.: Electrochim. Acta 246, 588-596 (2017)

78. Selva, T.M.G., Paixão, T.R.L.C.: Diam. Relat. Mater. 66, 113-118 (2016)

79. Belghiti, D.K., Zadeh-Habchi, M., Scorsone, E., Bergonzo, P.: Procedia Eng. 168, 428-431 (2016)

80. Wei, M., Zeng, G., Lu, Q.: Microchim. Acta 181, 121-127 (2014)

81. Soto-Hernandez, M., Palma-Tenango, M., del Garcia-Mateos, M.R.: Phenolic Compounds - Natural Sources, Importance and Applications. InTech (2017)

82. Lv, M., Wei, M., Rong, F., Terashima, C., Fujishima, A., Gu, Z.Z.: Electroanalysis 22, 199-203 (2010)

83. Tormin, T.F., Gimenes, D.T., Richter, E.M., Munoz, R.A.A.: Talanta 85, 1274-1278 (2011)

84. Janegitz, B.C., Medeiros, R.A., Rocha-Filho, R.C., Fatibello-Filho, O.: Diam. Relat. Mater. 25, 128-133 (2012)

85. Brycht, M., Lochyński, P., Barek, J., Skrzypek, S., Kuczewski, K., Schwarzova-Peckova, K.: J. Electroanal. Chem. 771, 1-9 (2016)

86. Vosáhlová, J., Koláčná, L., Daňhel, A., Fischer, J., Balintová, J., Hocek, M., Schwarzová-Pecková, K., Fojta, M.: J. Electroanal. Chem. 821, 111-120 (2018)

87. Kümmerer, K.: Pharmaceuticals in the Environment, (2008)

88. Aga, D.S.: Fate of Pharmaceuticals in the Environment and in Water Treatment Systems. CRC Press, Boca Raton (2008)

89. Wells, B.G., DiPiro, J.T., Schwinghammer, T.L., DiPiro, C. V.: Pharmacotherapy Handbook, n.d 
90. Feier, B., Gui, A., Cristea, C., Săndulescu, R.: Anal. Chim. Acta 976, 25-34 (2017)

91. Dönmez, F., Yardım, Y., Şentürk, Z.: Diam. Relat. Mater. 84, 95-102 (2018)

92. Rkik, M., Ben Brahim, M., Samet, Y.: J. Electroanal. Chem. 794, 175-181 (2017)

93. Ammar, H.B., Ben Brahim, M., Abdelhédi, R., Samet, Y.: Mater. Sci. Eng. C 59, 604-610 (2016)

94. Švorc, L., Sochr, J., Rievaj, M., Tomčík, P., Bustin, D.: Bioelectrochemistry 88, 36-41 (2012)

95. Švorc, L., Sochr, J., Tomčík, P., Rievaj, M., Bustin, D.: Electrochim. Acta 68, 227-234 (2012)

96. Pereira, P.F., Da Silva, W.P., Muñoz, R.A.A., Richter, E.M.: J. Electroanal. Chem. 766, 87-93 (2016)

97. Švorc, L., Cinková, K., Sochr, J., Vojs, M., Michniak, P., Marton, M.: J. Electroanal. Chem. 728, 86-93 (2014)

98. Medeiros, R.A., Baccarin, M., Fatibello-Filho, O., Rocha-Filho, R.C., Deslouis, C., Debiemme-Chouvy, C.: Electrochim. Acta 197, 179-185 (2016)

99. Pereira, G.F., Deroco, P.B., Silva, T.A., Ferreira, H.S., Fatibello-Filho, O., Eguiluz, K.I.B., Salazar-Banda, G.R.: Diam. Relat. Mater. 82, 109-114 (2018)

100. Silva, T.A., Pereira, G.F., Fatibello-Filho, O., Eguiluz, K.I.B., Salazar-Banda, G.R.: Diam. Relat. Mater. 58, 103-109 (2015)

101. Mansano, G.R., Eisele, A.P.P., Dall'Antonia, L.H., Afonso, S., Sartori, E.R.: J. Electroanal. Chem. 738, 188-194 (2015)

102. Eisele, A.P.P., Mansano, G.R., De Oliveira, F.M., Casarin, J., Tarley, C.R.T., Sartori, E.R.: J. Electroanal. Chem. 732, 46-52 (2014)

103. Lourencao, B.C., Medeiros, R.A., Fatibello-Filho, O.: J. Electroanal. Chem. 754, 154-159 (2015)

104. Gimenes, D.T., Marra, M.C., De Freitas, J.M., Abarza Muñoz, R.A., Richter, E.M.: Sens. Actuators B Chem. 212, 411-418 (2015)

105. Salamanca-Neto, C.A.R., Eisele, A.P.P., Resta, V.G., Scremin, J., Sartori, E.R.: Sens. Actuators B Chem. 230, 630-638 (2016)

106. Moraes, J.T., Salamanca-Neto, C.A.R., Švorc, L., Sartori, E.R.: Microchem. J. 134, 173-180 (2017)

107. Švorc, L., Strežová, I., Kianičková, K., Stanković, D.M., Otř́́sal, P., Samphao, A.: J. Electroanal. Chem. 822, 144-152 (2018) 
108. Oliveira, S.N., Ribeiro, F.W.P., Sousa, C.P., Soares, J.E.S., Suffredini, H.B., Becker, H., de Lima-Neto, P., Correia, A.N.: J. Electroanal. Chem. 788, 118124 (2017)

109. Oliveira, T.D.C., Freitas, J.M., Abarza Munoz, R.A., Richter, E.M.: Talanta 152, 308-313 (2016)

110. Švorc, L., Stanković, D.M., Kalcher, K.: Diam. Relat. Mater. 42, 1-7 (2014)

111. Freitas, J.M., Oliveira, T.C., Santana, M.H.P., Banks, C.E., Munoz, R.A.A., Richter, E.M.: Sens. Actuators B Chem. 282, 449-456 (2019)

112. Samiec, P., Švorc, L', Stanković, D.M., Vojs, M., Marton, M., Navrátilová, Z.: Sens. Actuators B Chem. 245, 963-971 (2017)

113. Stefano, J.S., Tormin, T.F., da Silva, J.P., Richter, E.M., Munoz, R.A.A.: Microchem. J. 133, 398-403 (2017)

114. Freitas, J.M., Oliveira, T.D.C., Gimenes, D.T., Munoz, R.A.A., Richter, E.M.: Talanta 146, 670-675 (2016)

115. Sartori, E.R., Clausen, D.N., Pires, I.M.R., Salamanca-Neto, C.A.R.: Diam. Relat. Mater. 77, 153-158 (2017)

116. Stanković, D.M., Kalcher, K.: Electrochim. Acta 168, 76-81 (2015)

117. Šelešovská, R., Kränková, B., Štěpánková, M., Martinková, P., Janíková, L., Chýlková, J., Vojs, M.: J. Electroanal. Chem. 821, 2-9 (2018)

118. Afkhami, A., Ghaedi, H., Madrakian, T., Ahmadi, M., Mahmood-Kashani, H.: Biosens. Bioelectron. 44, 34-40 (2013)

119. Santos, A.M., Vicentini, F.C., Figueiredo-Filho, L.C.S., Deroco, P.B., Fatibello-Filho, O.: Diam. Relat. Mater. 60, 1-8 (2015)

120. Marciano, F.R., Bonetti, L.F., Da-Silva, N.S., Corat, E.J., Trava-Airoldi, V.J.: Synth. Met. 159, 2167-2169 (2009)

121. Oh, H.G., Lee, J.Y., Son, H.G., Kim, D.H., Park, S.H., Kim, C.M., Jhee, K.H., Song, K.S.: Results Phys. 12, 2129-2135 (2019)

122. Majid, E., Male, K.B., Luong, J.H.T.: J. Agric. Food Chem. 56, 7691-7695 (2008)

123. Matsumoto, T., Tatsuno, I., Hasegawa, T.: Water (Switzerland) 11 (2019)

124. Furuta, T., Tanaka, H., Nishiki, Y., Pupunat, L., Haenni, W., Rychen, P.: Diam. Relat. Mater. 13, 2016-2019 (2004)

125. Švorc, L., Cinková, K., Samphao, A., Stanković, D.M., Mehmeti, E., Kalcher, K.: J. Electroanal. Chem. 744, 37-44 (2015) 
126. Ali, H.S., Abdullah, A.A., Pınar, P.T., Yardım, Y., Şentürk, Z.: Talanta 170, 384-391 (2017)

127. Garcia-Segura, S., Keller, J., Brillas, E., Radjenovic, J.: J. Hazard. Mater. 283, 551-557 (2015)

128. Garcia-Segura, S., Ocon, J.D., Chong, M.N.: Process Saf. Environ. Prot. 113, 48-67 (2018)

129. Loos, G., Scheers, T., Van Eyck, K., Van Schepdael, A., Adams, E., Van der Bruggen, B., Cabooter, D., Dewil, R.: Sep. Purif. Technol. 195, 184-191 (2018)

130. Lan, Y., Coetsier, C., Causserand, C., Groenen Serrano, K.: Chem. Eng. J. 333, 486-494 (2018)

131. Candia-Onfray, C., Espinoza, N., Sabino da Silva, E.B., Toledo-Neira, C., Espinoza, L.C., Santander, R., García, V., Salazar, R.: Chemosphere 206, 709717 (2018)

132. He, Y., Lin, H., Guo, Z., Zhang, W., Li, H., Huang, W.: Sep. Purif. Technol. 802-821 (2019)

133. Olvera-Vargas, H., Oturan, N., Oturan, M.A., Brillas, E.: Sep. Purif. Technol. 146, 127-135 (2015)

134. Moreira, F.C., Boaventura, R.A.R., Brillas, E., Vilar, V.J.P.: Appl. Catal. B Environ. 202, 217-261 (2017)

135. Kanakaraju, D., Glass, B.D., Oelgemöller, M.: J. Environ. Manage. 219, 189-207 (2018) 